\title{
A Framework for Managing the Biophysical Effects of Tourism on the Natural Environment in New Zealand
}

\author{
Jonet Ward, Ken Hughey and Steven Urlich \\ Environmental Management and Design Division, P.O. Box 84, Lincoln \\ University, New Zealand
}

Tourists in New Zealand often impact on the natural environments that are the very reason for their visits. It is, therefore, necessary to manage those natural environments to help ensure that tourism is an environmentally sustainable activity. To assist that management process, it is helpful to establish an overarching classification framework so that consistent guidelines and environmental performance standards can be applied. This paper describes a framework for management of the biophysical impacts of tourism using a natural environment classification of the assets visited by tourists. 'Best available information' is then used to develop indicators of environmental change and associated guidelines for management at a range of levels. As a minimum, broad guidelines can be developed for the upper levels of each component of the classification. More detailed and site-specific guidelines are available in some circumstances, where appropriate research has been undertaken. Ongoing evaluation of the combination of indicators and guidelines establishes if the natural attraction is being sustainably managed. The system has been applied to 'scenic icons', wildlife attractions and caves on the West Coast of the South Island.

\section{Introduction}

\section{Rationale for classifying natural tourism assets}

Tourism is one of New Zealand's largest export earners, generating $16 \%$ of the nation's export earnings. There has been an $85 \%$ growth in international visitors over the last 10 years; current visitor numbers of 1.8 million per annum are projected to increase to 2.5 millions per annum in 2006 (Tourism Strategy Group, 2001). Growing numbers of visitors have put pressure on tourism operators and managers to effectively avoid, remedy and/or mitigate the existing and potential effects of tourism, whilst at the same time providing visitors with a quality experience and running profitable enterprises. A major review and investigation into the environmental effects associated with the tourism sector was recently carried out by the Parliamentary Commissioner for the Environment (PCE, 1997a). However, standard tools for identifying and monitoring visitor impacts, and generic guidelines for management, are currently not widely applied by, or available to, many operators in New Zealand.

There are several important factors that have influenced this situation and which need to be considered in developing a broad framework for managing the effects of tourism on the natural environment in New Zealand. [Note that in this paper visitor 'effects' are defined as the physical consequences and processes 


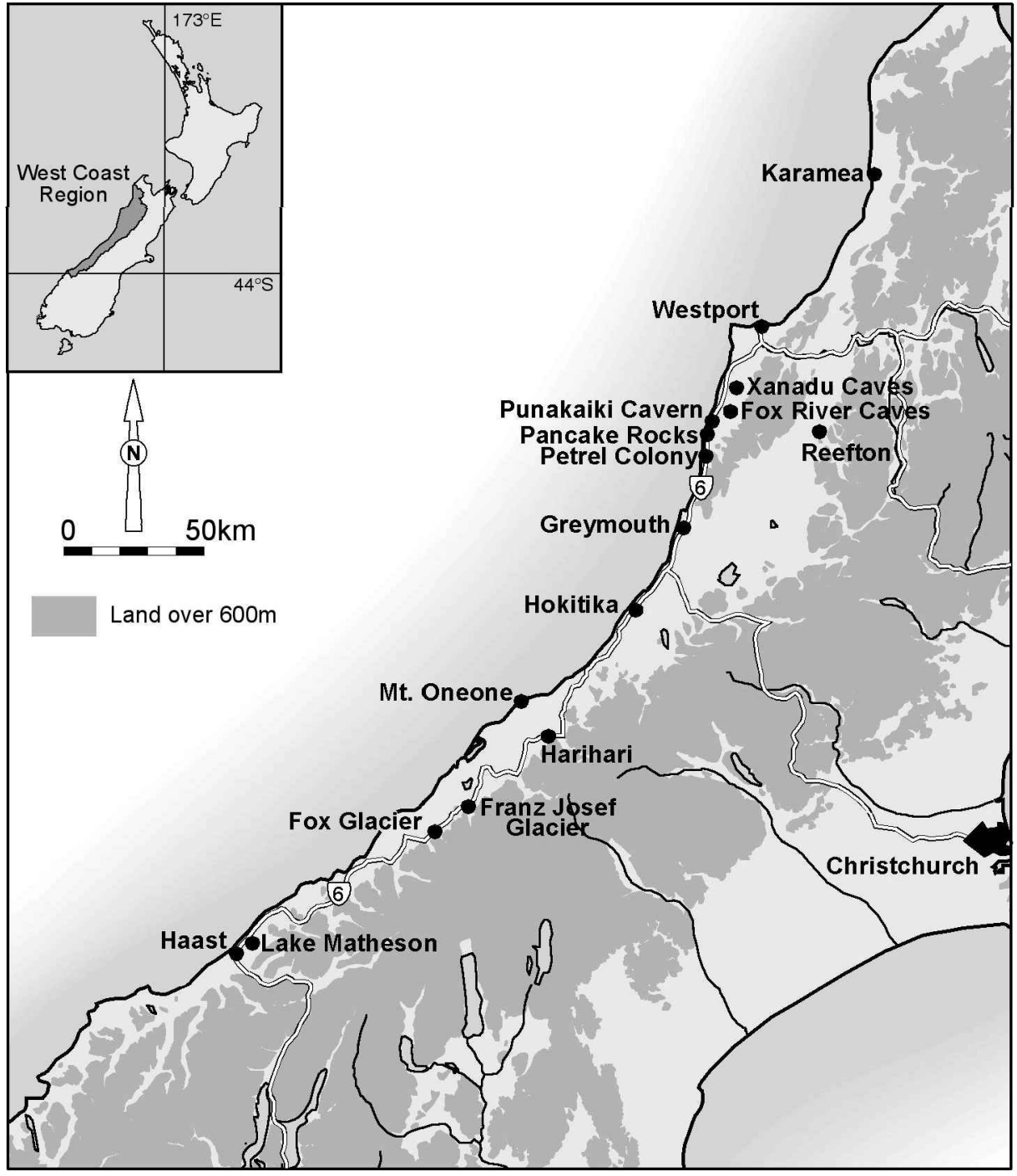

Figure 1 Map of the West Coast of the South Island showing study sites

associated with the presence of visitors in natural settings, which are natural phenomena and may or may not be adverse, while visitor 'impacts' are the specific adverse effects of visitors that represent tangible threats to key conservation values specified by management (Cessford, 1997: 7).] First, impacts can occur which are site-specific, making it difficult to generalise between different attractions, due to the particular set of environmental conditions, species characteristics, or type of activity occurring (Kuss et al., 1990). Second, there is the issue of determining the relative ecological significance of visitor impacts on biophysical assets in relation to other ecosystem processes - the 'so-what?' question (Cessford, 1997, 1999a). This varies in different systems depending on the resilience of the attraction in recovering after disturbance (e.g. Marion \& Farrell, 
1998); for example, recovery from visitor impacts may be relatively quick for tracks in some forest types on the West Coast ${ }^{1}$ of the South Island of New Zealand (Figure 1) compared to the more sustained and permanent alterations of visitor impacts in low energy cave ecosystems (Urlich et al., 2001). Third, social and managerial impacts may be relatively more significant in some areas than biophysical impacts, in terms of visitor experience, crowding, conflicts and displacement (e.g. Kearsley \& O'Neill, 1994). Fourth, there has been a general lack of integrated application of visitor planning frameworks in managing attractions to maintain desired conditions and monitoring key performance indicators accordingly (Booth \& Cullen, 1995; McArthur, 1999).

The Recreation Opportunity Spectrum (ROS) framework (Clark \& Stankey, 1979) allows for the management of various recreation experiences based on access, other non-recreational uses, site modifications, social interaction, acceptability of visitor impacts and acceptable levels of management. The Limits of Acceptable Change (LAC) process (Stankey et al. 1985) focuses on wilderness planning with explicit objectives and opportunity classes for different management approaches. Management decisions focus on bringing back or maintaining the desired state for each opportunity class. The Visitor Impact Management (VIM) model is a planning framework for controlling or reducing undesirable impacts of recreational use (Graefe, 1993). It is a step-by-step process for identifying impacts, their causes and effective management that can be used as a management tool for localised impacts. McArthur (2000) introduced a large Tourism Optimisation Model (TOMM) to monitor and manage visitor activity. It was developed to improve sustainable forest use by better integrating visitor and forest management and was designed to service a variety of stakeholders with many interests and values over public and private lands.

Another approach is to develop a framework that assists managers in devising indicators of acceptable environmental change by first classifying natural attractions and then selecting appropriate indicators for management. Guidelines for managing environmental effects from tourist activities identified by monitoring the key indicators are also needed, as a tool for helping asset managers.

This paper deals only with the biophysical aspects of the tourism impact spectrum. We propose a framework that integrates the needs of tourism operators and environmental managers. Development of this framework is part of a programme funded by the New Zealand Foundation for Research, Science and Technology: 'Indicators of acceptable environmental change caused by tourism for environmental systems on which tourism depends'. The project stems from the results of the Parliamentary Commissioner for the Environment's report (1997a) mentioned above. It uses a modified version of the LAC process (that we call 'limits of acceptable environmental change') in that biological experts and an advisory panel of managers and operators were consulted rather than a full range of stakeholders. The aims of this paper are to describe a framework that:

(1) Classifies natural assets visited by tourists, which can be widely applied.

(2) Identifies indicators of environmental change that are generic to a particular class of a particular asset type.

(3) From these indicators, provides management guidelines to aid in developing limits of acceptable environmental change for these assets. 


\section{Method}

The classification system was devised with reference to various literature reviews of tourism impacts on natural assets (Booth \& Cullen, 1995; Cessford, 1997; Constantine, 1999; Kuss et al., 1990; Parliamentary Commissioner for the Environment, 1997b; Walls, 1999; Ward and Beanland, 1995, 1996), and from concurrent research into tourism impacts on natural assets on the West Coast of the South Island of New Zealand (Urlich et al., 2001). A draft classification was circulated to tourism policy makers, managers and operators in Wellington and on the West Coast of the South Island. It was revised following feedback and dialogue with participants at two tourism stakeholder workshops held in Wellington and Hokitika (Figure 1) in May and June 2000, respectively.

Our goal was to develop a classification system of natural assets for tourism that is clearly set out, simple to use, amenable to future development, and practical in its operation. To achieve this, we produced a system that integrates combinations of different natural attractions and associated visitor activity(s). The inter-linking parts of the attraction dynamic in New Zealand include diverse combinations of living organisms (e.g. penguins, dolphins, whales, plants), environments (e.g. marine, freshwater, terrestrial), heritage, and tourism activities (e.g. walking, viewing, swimming). This information is presented by identifying elements common to a number of assets and placing these in one of three broad asset types. Within each asset type, assets are subdivided into distinct asset classes.

In addition, for each asset class, indicators of environmental effects common or generic to a particular asset class are identified. Guidelines for management of environmental effects identified by the generic indicators are also presented. The conceptual expression of this integration is presented in two flow diagrams (Figures 2 and 3). Final application of these approaches includes a Decision Support System (DSS) (Microsoft Access based) that will be associated with a geographical information system (GIS) application. A framework for this DSS is presented in Figure 4.

While the classification system, indicators and guidelines are intended to apply to New Zealand as a whole, the West Coast region of the South Island (Figure 1) was used as a case study area for detailed studies.

\section{Environmental Classification Systems in New Zealand}

The New Zealand Biodiversity Strategy (Department of Conservation and Ministry for the Environment, 2000) identified the protection and enhancement of indigenous biodiversity as the most important environmental challenge for New Zealand. Protecting indigenous biodiversity not only applies to the management of conservation objectives (Stephens, 1999) but also to different sectors that work in the natural environment. For the tourism industry, biodiversity protection is a key management consideration with respect to avoiding habitat degradation (e.g. pollution, alteration of natural features) and / or direct effects on species (e.g. spatial and temporal displacement, local extinction). This is because the long-term health and condition of these assets is vital to ongoing sustainable tourism in the environment. Therefore, a means of classifying assets is a necessary step in devising standard monitoring tools and guidelines for managers in working towards sustainable visitor management at 
the individual attraction level. Classification of tourism attractions not only provides a framework that can be widely applied and easily understood but is also a practical system that has the benefits of facilitating information and communication between different managers of similar attractions. The tourism asset classification system has to incorporate differing combinations of environments (e.g. marine, freshwater, terrestrial) and tourism activities (e.g. walking, viewing, swimming), and/or species (e.g. penguins, dolphins, whales), associated with tourism attractions within the country.

There are several approaches to classifying natural assets that work at different scales, primarily either at the taxonomic level (i.e. the Linnaean system) or at the ecological level (Stephens, 1999). The Maori people in New Zealand had their own system of classification. For example, Park (1995: 47) noted that in the 1870s, from a few North Island districts alone, the botanist James Hector recorded some 70 Maori names for different flaxes, where the Linnaean system recognised two species. Each of the 70 was known for its special use. At the ecological level, there are a number of different ecologically based classification systems reflecting the mix of physical and biological characteristics unique to different ecosystems. For example, there are classifications devised for cave ecosystems based on cave geomorphology (Worthy, 1990), vegetation types based on community composition (Newsome, 1987), and wetlands based on hydrology (Ward \& Lambie, 1999). There are elements of these systems that can be used and incorporated in an overall tourism asset classification.

Other classifications have primarily been based around a GIS approach (Brabyn, 1996; Kliskey \& Kearsley, 1993). These used a range of physical attributes, and/or perceptions of naturalness, to group together and map environments on the basis of similarity in these attributes; for example, landscape character (Brabyn, 1996), and visitor perceptions of wilderness (Kliskey \& Kearsley, 1993).

Other approaches to ecological classification have been based around grouping together species on the basis of their distributions in relation to environmental variability (Stephens, 1999). McEwen (1987) classified species distributions into broad ecological regions and districts in relation to environmental pattern, disturbance, geological, and biogeographical histories. Different plant species have also been grouped into communities on the basis of similar environmental tolerances (e.g. landform, slope, aspect, drainage, etc.) using regression modelling (Leathwick, 1995, 1998). All these classification approaches are attribute, scale and context dependent (Stephens, 1999), and whichever system is used relates to the purpose of the study and/or the management goals (i.e. which species/communities are the focus and at what level information is needed).

The New Zealand Department of Conservation $(\mathrm{DoC})$ has been developing a classification system for management of biophysical resources. The classification is focused on the goal of providing an assessment of output conservation value, in terms of financial cost versus native biodiversity protection and enhancement (Stephens, 1999). This system focuses on the indigenous ecosystem attributes (i.e. natural character) affected by human activity. For example, natural character is a reflection of biodiversity loss from human activities and is measurable on a number of scales, including landscape fragmentation, abundance of plant and animal pests, and changes to disturbance regimes. The connection to the tourism natural asset classification for sites managed by DoC lies in integrated landscape 

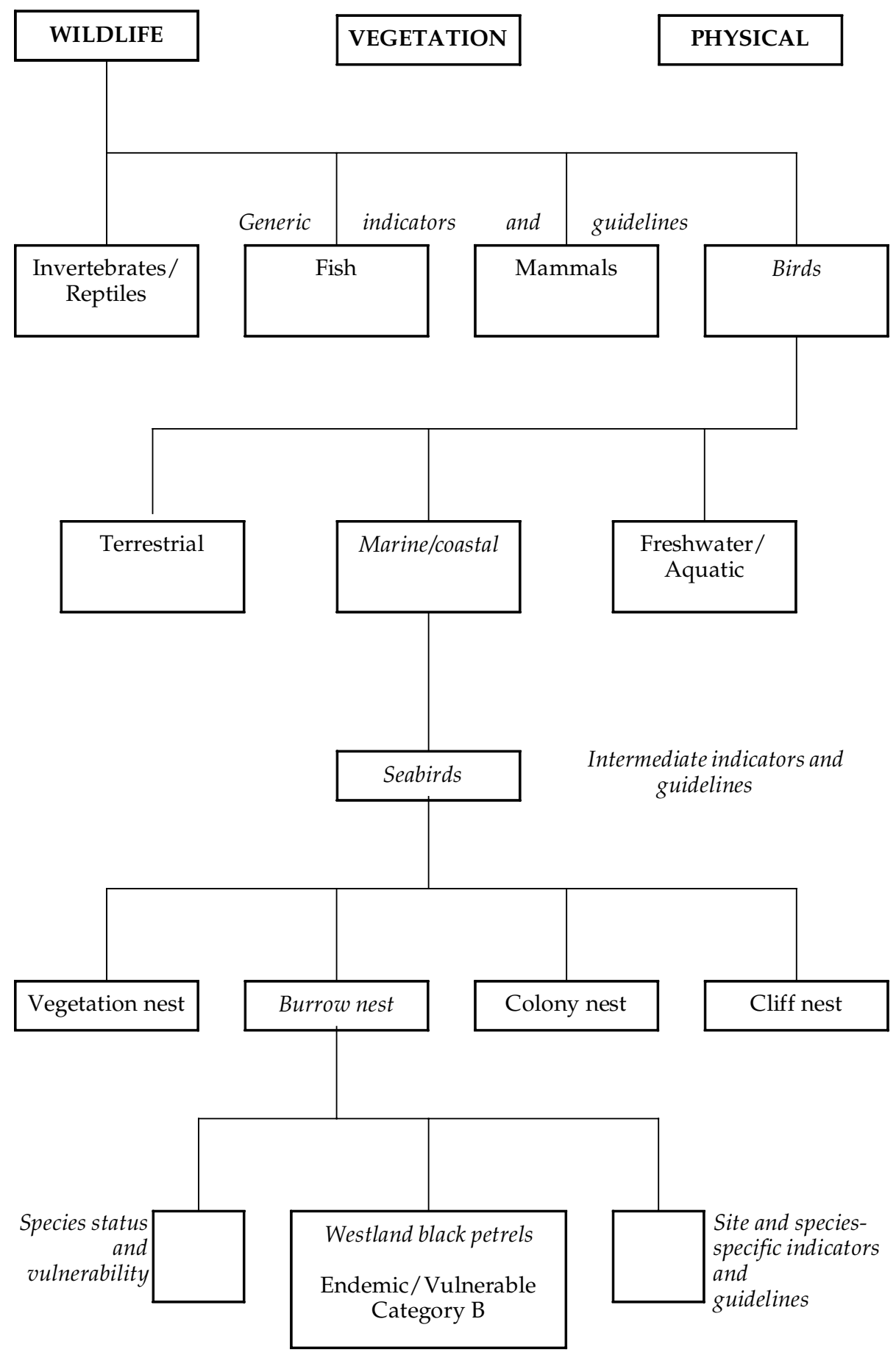

Figure 2 Natural asset classification of tourism using a generic to specific approach with wildlife-birds used as example 
management where visitor sites managed by $\mathrm{DoC}$ are part of larger biodiversity management programmes, and in the protection and/or enhancement of biodiversity at individual sites (e.g. fur seals). These different sites can also be linked in as part of a network of biodiversity indicator sites.

\section{Tourism Natural Asset Classification}

The tourism natural asset classification system specifically focuses on tourism in the environment that is attraction based, and accordingly enables the development of indicators of environmental effects to be formulated around the different activities of visitors at these attractions (Figs. 2 and 3). This classification can be used either from the broad generic level down to the site specific level, or from the specific to the general. Managers can, therefore, choose the appropriate level for their needs. At the generic level, three broad groups of different assets or attraction types are identified: wildlife, vegetation and physical. These types are further divided into asset classes, e.g. wildlife includes birds, mammals, fish and invertebrates/reptiles as the primary attraction. The selection of appropriate indicators comprises a combination of generic indicators common to all attractions of a particular class of an asset type, and site-specific indicators which relate to the unique characteristics of the individual attraction (e.g. geology, species behaviour, etc). For example, indicators common or generic to all wildlife include spatial and/or temporal displacement of the target species, whereas a sitespecific indicator could relate to the behavioural characteristics of a particular species of a particular class, such as the shyness of the Fiordland crested penguin (Eudyptes pachyrhynchus) towards visitors (McLean, 1995; Urlich et al., 2001). Some assets naturally incorporate elements from more than one attraction type (e.g. geothermal sites - physical and vegetation; seals - wildlife and physical). However, attractions are placed into types which are the primary focus and reason for visitation (e.g. geothermal - physical; seals - wildlife). We chose these groups because they cover the variety of assets likely to be encountered in nature, and because they are terms understood by managers, operators and the public alike, i.e. they are useful.

For the indicators at each level, there will be guidelines associated with management in response to these indicators. For the wildlife example of birds presented in Figure 2, a generic indicator related to species behaviour may include spatial displacement of birds to less preferred areas, where they avoid visitors and much visitor contact (Robertson, 1993). A management guideline in response could be to restrict visitor numbers or timing of visits, or to construct or alter viewing structures to avoid or reduce stress to the birds (Robertson, 1993). At the site level, these guidelines might apply to a particular species.

Individual species are popular attractions for tourists, including the white heron (Egretta alba), yellow-eyed penguin (Megadyptes antipodes), royal albatross (Diomedea epomophora) and Westland black petrel (Procellaria westlandica). There are also areas where visitors go to witness natural phenomena involving many bird species such as the annual migration at Miranda in the Firth of Thames (North Island). Accordingly, the classification for wildlife-birds is further divided into the different environments where they predominantly feed or 
inhabit (e.g. freshwater for the white heron, marine/coastal for species such as the Westland black petrel) (Fig. 2).

Within these environments, there are differences in species ecology that influence the selection of indicators at the intermediate level. For example, pelagic seabirds that breed on the mainland will have different management requirements for tourism than migratory, non-breeding estuarine waders that congregate at Miranda in the Firth of Thames. Fledging success is an intermediate indicator associated with the tourism at seabird sites such as the Westland black petrel or Fiordland crested penguin. A management guideline in response may be to monitor bird population dynamics over time, in conjunction with generic indicators such as species behaviour, to examine how tourism activities are affecting the long-term viability of the particular colony. To gain an understanding of the relative importance of different factors on the well-being of the colony, a range of different indicators at the generic, intermediate, and site-specific levels can be monitored in combination over time. These factors may include predator abundance and diversity, food supply, visitor activities, and bird behaviour in response to visitor activities at different times.

The classification of wildlife-birds-seabirds is further divided by the mode of breeding, as site-specific indicators will apply at different types of colonies (Fig. 2). For example, some species breed in large, open colonies such as the gannets at Cape Kidnappers (North Island); others breed on cliff faces, like the shags at Whitewash Head in Christchurch, or there are burrow nesters, like the Westland black petrel located near Westport (Fig. 1) that dig into mudstone ridges underneath coastal hardwood forest. Site-specific indicators of visitor activities at a Westland black petrel colony for instance, could include the level of burrow damage and/or erosion caused by visitors.

The physical asset classes in Figure 3 are based on the predominant environment or setting of which the individual attraction is a special and/or unique part. Some examples of physical asset classes include caves-karstecosystems and marine/ coastal-marine reserves. Figure 3 shows an example of a physical asset, in this case the Fox River Caves near Punakaiki on the West Coast (Fig. 1). The classification of caves is based on Worthy's (1990) classification. Generic indicators of visitor impacts in caves include structural damage/vandalism, pollution, mud / sedimentation, and changes in cave fauna community composition. The classification is divided by the type of environment where caves are located, in terrestrial or marine/coastal, and the type of formation and parent material of the caves (Fig. 3). Some karst caves will have an intermediate indicator based around the condition of speleothems. There will be site-specific indicators and guidelines based on geomorphology, ecology (including endemic and/or rare species) and fossil history (Urlich et al., 2001) depending on the access arrangements for individual caves and/or cave passages.

The vegetation asset classes include a number of scenic icon sites. In the case of vegetation-forests-icon trees, such as the Giant Matai (Prumnopitys taxifolia) at Lake Ianthe in south Westland near Harihari (Fig. 1), site specific indicators and associated management guidelines are necessary which may not be applicable to other surrounding trees in the forest. This is due to the values associated with individual trees conferred by size, longevity and/or rarity. For example, the Giant Matai is not only an attraction for its large size and great longevity, it supports a 


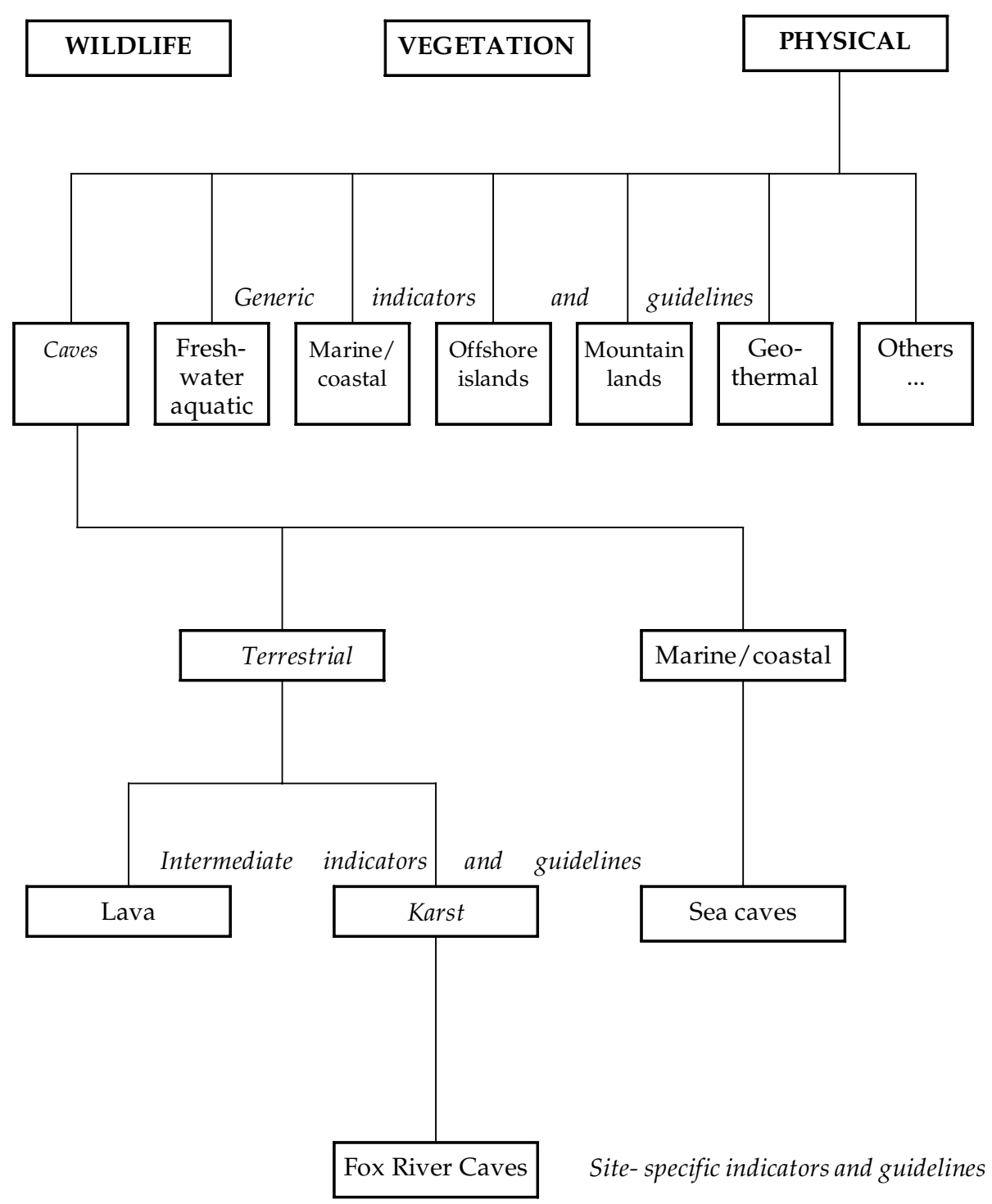

Figure 3 Natural asset classification of tourism under physical-caves as an example 
comparatively high level of biodiversity compared to other surrounding forest trees with a diverse community of epiphytes, shrubs and small trees. Therefore, there will be specific indicators of visitor effects for this tree's health that may differ from the generic indicators of forest health identified and monitored in the surrounding forest. For other icon trees such as Tane Mahuta (giant Kauri Agathis australis) in Waipoua Forest, Northland, managers have placed barriers to keep visitors away from trampling the sensitive root systems.

Therefore, the higher level of protection for heavily visited scenic icon sites means management guidelines can be more specific than for other sites in the same class. This is also the case for other scenic icon sites within the physical asset classes, for example, physical-freshwater aquatic-lakes-Lake Matheson. Lake Matheson in south Westland (Fig. 1) receives about 100,000 visitors per year and is managed with respect to the scenic attributes, as well as with sensitivity to its reflective qualities (T. Preston, DoC Fox Glacier, pers comm). Other lakes in the region share generic guidelines for visitor management as Lake Matheson, but do not have the same qualities and/or accessibility.

The physical attributes of attractions include both the site infrastructure and the means by which visitors reach different types of attractions such as tracks, walkways, bridges and platforms. These structures have to comply with legislative requirements and/or prescriptive standards for construction, maintenance and safety. In this respect, there are generic indicators and management guidelines that are common to many different types and classes of attractions.

For tracks/walkways that are attractions in themselves, such as the Kepler Track in Fiordland and Heaphy Track near Karamea (Fig. 1), DoC have prescribed management standards which cover the environmental management of visitor effects. We classify these track assets as a separate class within the physical asset type grouping, and apply the generic indicators of visitor environmental effects and guidelines from this class to the infrastructural attributes of other attraction classes.

\section{Indicator Selection}

The choice of indicators under the LAC planning framework requires managers to define how much change is acceptable. Visitor opinions can also be used to set standards and these may vary according to use and experience (Roggenbuck et al. 1993). Hall \& McArthur (1998) suggest that indicator selection needs great care and must reflect the organisation's strategic objectives. Criteria may be used to assess the merits of each indicator. These may include ease of comprehension by all parties, any requirements for flexibility, and the need to avoid political bias.

McArthur (2000) developed indicators with stakeholders for the TOMM model so that a tangible measure of the optimum condition could be identified and monitored. Most of these are social and management indicators reflecting visitor experience, economic and market opportunities. A small proportion are environmental indicators. VIM identifies social and ecological indicators and standards are selected for key indicators that are quantitative statements of desired conditions (Graefe, 1993). The problems associated with the selection of 
the most appropriate indicator for optimal condition are common to the LAC, TOMM and VIM frameworks (McArthur, 2000).

The modified LAC (limits of acceptable environmental change) approach used in this study and the classification presented allows for selection of indicators at a range of levels. Those biophysical indicators that are monitored for change should be related and responsive to the desired conditions selected by managers for the asset over the long-term. Consultation with tourism managers and operators is occurring about the long term sustainability of the asset and selection of indicators to be monitored.

The selection of key biophysical indicators for a monitoring programme of visitor effects on an asset needs to fulfil a range of criteria. They should be policy relevant, analytically valid, cost-effective, simple and easily understood (Ministry for the Environment, 1997). Indicators for tourism effects may be predictive, descriptive, show trends over time, and be capable of illustrating the relationship between visitors and environmental effects (Ward \& Beanland, 1995). Indicators in this sense should not only detect or provide early warning of deterioration of environmental quality, or the introduction of hazards, at an asset, they should also be sensitive enough, ideally, to identify and enable the avoidance of irreversible negative change. Therefore, the indicators of acceptable environmental change should reflect a relationship between the amount and/or type of use occurring and responses to management actions. Biophysical indicators of asset condition can also be complemented by social indicators (visitor experience, behaviour, crowding, etc.) (Cessford, 1999b).

Indicators of tourism effects at some sites may also have some overlap with and contribute to the New Zealand national environmental indicators programme developed by the Ministry for the Environment (MfE, 1997). Table 1 shows a number of environmental indicators of potential visitor impacts to be monitored based on Ward and Beanland (1995) and the Parliamentary Commissioner for the Environment (PCE, 1997b).

The resilience and tolerance of assets to disturbance is a key factor for managers to consider when assessing the impacts of visitors (e.g. Kuss et al., 1990). Accordingly, in selecting indicators managers need to carefully consider relative use-impact relationships from different visitor activities, by assessing the capacity of the asset to accommodate existing and projected visitor numbers, and changes in the intensity and nature of visitor activities (Ward \& Beanland, 1995).

\section{Management Guidelines}

There are a number of strategies for managing the impacts of visitors such as those listed by Hall and McArthur (1998), Hammitt and Cole (1998) and Carden (1998). Hall and McArthur list 16 management techniques ranging from regulating access and promotional marketing to developing alternative provision. Each of these techniques is qualitatively assessed for its ability to conserve heritage directly and to improve the quality of the visitor experience. Marketing, interpretation, the use of volunteers, and favouring accredited organisations for bringing visitors to a site were found to be particularly effective management 
Table 1 Development of indicators for the environmental impacts of tourism

\begin{tabular}{|l|l||}
\hline $\begin{array}{l}\text { Potential } \\
\text { environmental impact }\end{array}$ & Indicator \\
\hline Vegetation degradation & $\begin{array}{l}\text { Area degraded, change in species composition and } \\
\text { community structure, \% cover of introduced weeds, } \\
\text { cumulative use of site, soil type, slope, climate. Damage } \\
\text { and/or mortality to icon trees. Growth and survival of } \\
\text { restoration plantings. Inappropriate track construction and } \\
\text { placement. }\end{array}$ \\
\hline $\begin{array}{l}\text { Soil erosion and } \\
\text { compaction }\end{array}$ & $\begin{array}{l}\text { Total area affected, \% bare ground, slope, aspect, soil type, } \\
\text { climate. Multiple track formation in boggy areas. }\end{array}$ \\
\hline $\begin{array}{l}\text { Wildlife behaviour } \\
\text { varies within and } \\
\text { between species) }\end{array}$ & $\begin{array}{l}\text { Loss of habitat, food supply, change in feeding patterns, } \\
\text { breeding success, effect on productivity resulting in } \\
\text { disturbance of essential functions, severe exertion, } \\
\text { displacement, death. Habituation/imprinting. }\end{array}$ \\
\hline $\begin{array}{l}\text { Reduced biodiversity } \\
\text { abecies numbers. Number of invasive species. Predator } \\
\text { abundance/diversity. Habitat loss/fragmentation. }\end{array}$ \\
\hline $\begin{array}{l}\text { Impacts on selected } \\
\text { species or groups of } \\
\text { species }\end{array}$ & $\begin{array}{l}\text { Population levels, general health, resilience to impacts } \\
\text { (function of size of impacts and significance to species). }\end{array}$ \\
\hline $\begin{array}{l}\text { Indirect effects on other } \\
\text { species (e.g. birds, } \\
\text { rodents, reptiles, } \\
\text { insects) }\end{array}$ & $\begin{array}{l}\text { Changes in species behaviour, productivity, etc. Amount of } \\
\text { litter. }\end{array}$ \\
\hline $\begin{array}{l}\text { Negative effects of } \\
\text { crowding, structures }\end{array}$ & $\begin{array}{l}\text { Complaints, reduced visitor numbers. Spatial/temporal } \\
\text { displacement, Pressure on non-target areas. Visitor } \\
\text { behaviour. }\end{array}$ \\
\hline $\begin{array}{l}\text { Pollution - water, } \\
\text { sewage and waste } \\
\text { disposal, litter }\end{array}$ & $\begin{array}{l}\text { Level of use, faecal coliforms, giardia, erosion and } \\
\text { sedimentation, flow and dilution rates, nutrient enrichment, } \\
\text { amount sewage discharged, waste produced, litter collected. }\end{array}$ \\
\hline $\begin{array}{l}\text { Noise from air, road or } \\
\text { boat traffic }\end{array}$ & $\begin{array}{l}\text { Complaints, reduced visitor numbers. Wildlife disturbance. } \\
\text { Visitor behaviour. }\end{array}$ \\
\hline $\begin{array}{l}\text { features } \\
\text { character. }\end{array}$ \\
\hline
\end{tabular}

techniques for both these goals. Hammitt and Cole (1998) discuss management strategies for reducing impacts including reducing the amount of use, timing of use, modifying visitor behaviour and site hardening. Any one strategy can be used for a variety of problems but it is recognised that some may have negative implications and management overkill might not always be appropriate. Where regulations are applied, they should be at the minimum level possible. It is also important that they are understood and enforced.

In New Zealand, the Department of Conservation (DoC) has a range of potential management tools outlined to deal with visitor impacts where values and environmental conditions are at risk of degradation (Carden, 1998:16-17). These include: 
- reduce the use of the site by restricting visitor numbers;

- modify visitor activities and behaviour mainly through interpretation and education;

- modify the timing of visitor activities;

- move the activity/facility/service somewhere else better able to cope;

- and/or increase the site resistance by barriers to separate visitors from the target resource.

Additionally, there are regulatory and legislative tools that managers can utilise, depending on the status and condition of the asset (Cessford \& Dingwall, 1997).

Careful construction and placement of visitor infrastructure can minimise visitor effects on the target attraction as well as meet safety requirements for visitors. Regular site maintenance can also convey a message to visitors of strong management care and guardianship (Urlich et al., 2001). Research and monitoring are also key management guidelines, particularly with respect to the relative effects of different types of visitor activities on wildlife (e.g. species behaviour, displacement, population dynamics). An additional research guideline is to undertake a regular visitor survey(s) that encompasses environmental and social experiences of visitors at individual sites. The results can then be linked back into the modified version of the LAC process to help in achieving the goal of sustainable management of tourism in the natural environment.

Identification and classification of like-assets can be improved by introducing a GIS framework. A system which incorporates locations of important wildlife sites, important vegetation and the physical environment will help identify areas where there are interactions between assets occurring at the same place. Where such overlaps occur (and even when they do not) a relational database can be used to drive a Decision Support System (DSS) for the identification, from pick lists, of indicators and management guidelines. The output will be a set of indicators and guidelines relevant to the natural asset and the tourism activities. A sample framework for a DSS is presented in Figure 4.

After the asset is classified as to type and the tourist activity is identified, the operator/manager can select impacts or potential impacts at the level appropriate to the classified asset (generic, intermediate or site specific level). From here the relevant indicator and management guidelines can be selected. Tables 2 and 3 provide examples of the sort of information that could be contained within pick lists of impacts, indicators and guidelines. These are linked to the main tourist activities at the attractions.

Table 2 shows an example of viewing a wildlife attraction, specifically an albatross colony, while Table 3 shows an example of visiting caves, specifically a track leading to the Fox River Caves (Fig. 1).

\section{Conclusions}

Much progress has been made on identifying the effects of tourism on natural assets and on devising site specific management for those impacts. However, there has been, until now, no overall framework developed with sufficient detail to provide for consistent and integrated management of the effects of tourism on the natural environment in New Zealand. 


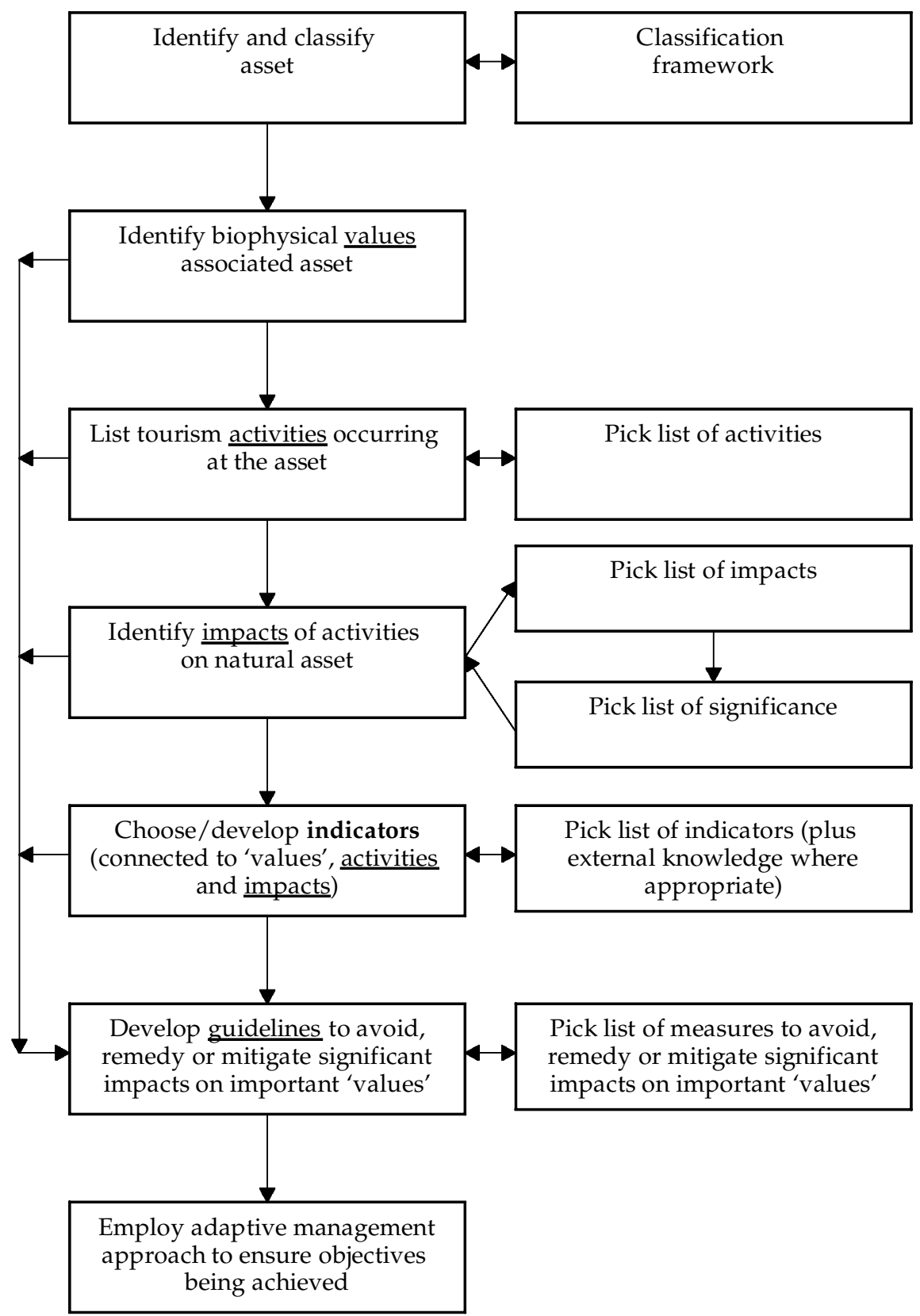

Figure 4 Sample Decision Support System framework for managing tourism and natural assets 

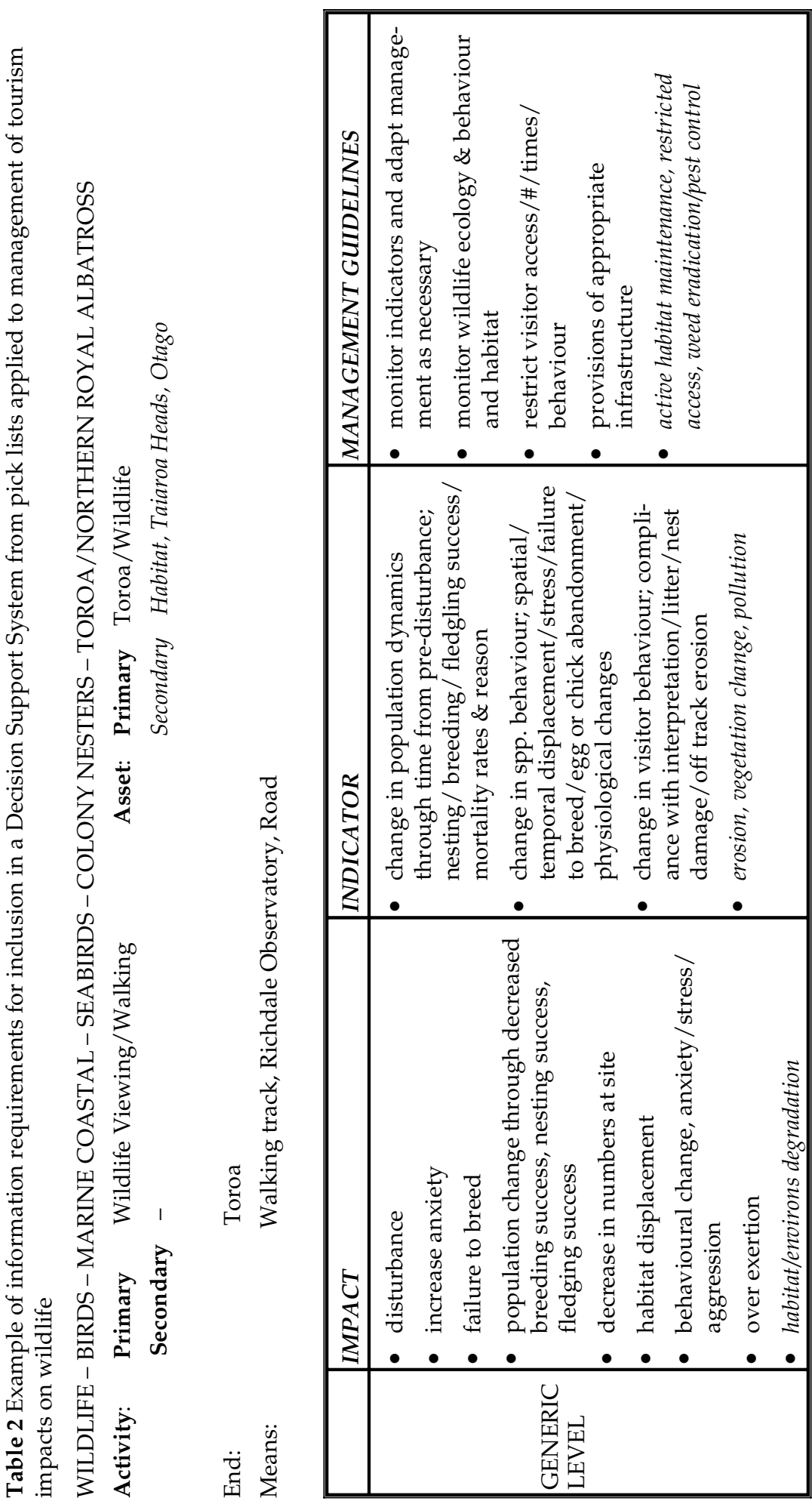


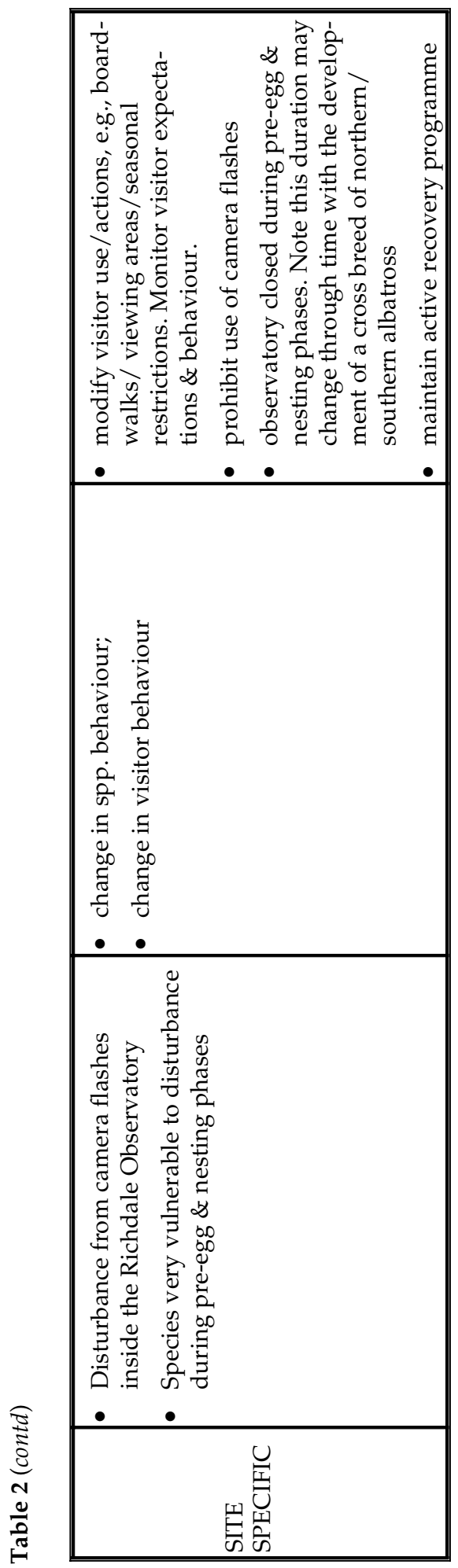



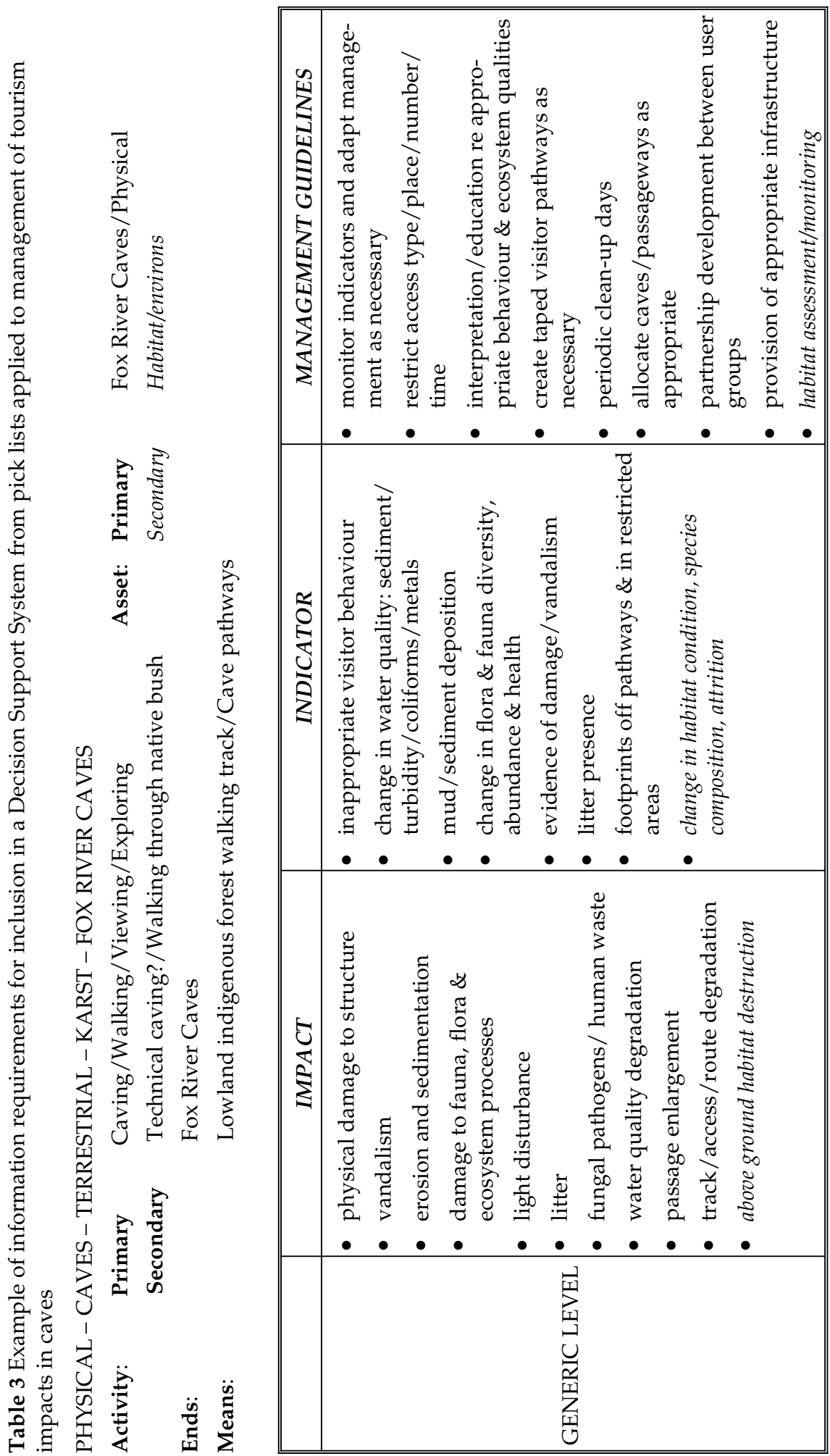


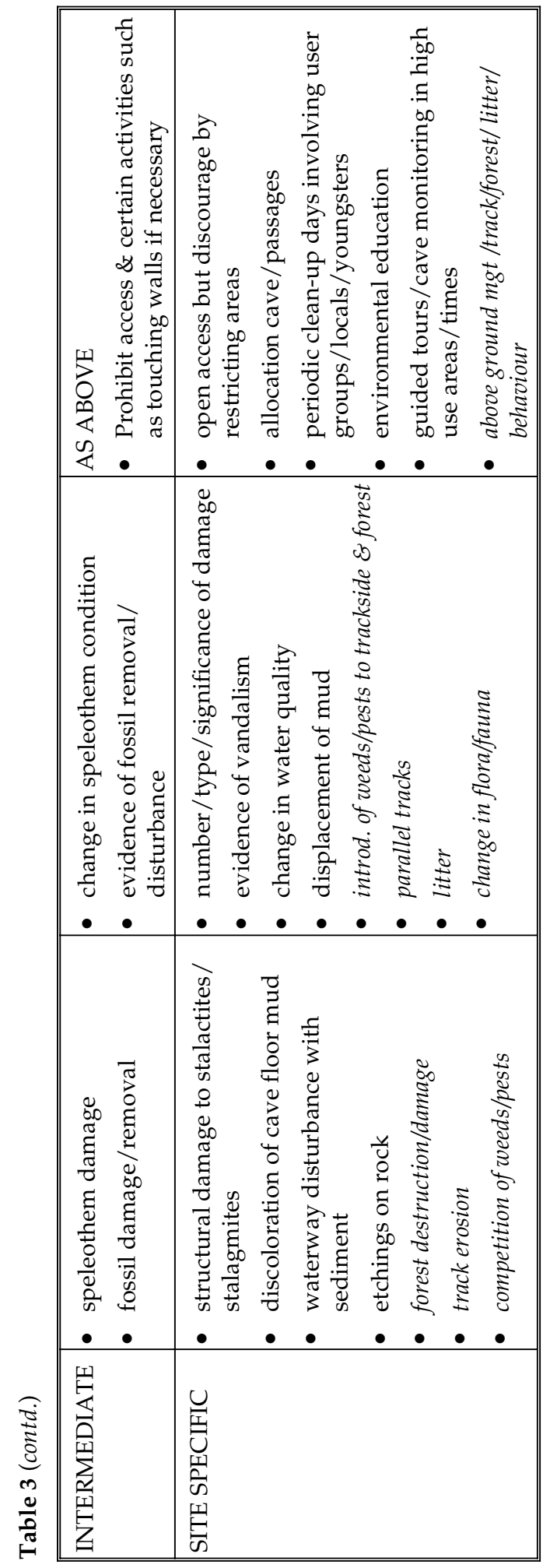


The framework developed here focuses on the management of biophysical impacts of tourism. It involves a classification of the assets in relation to visitor activity, identification of indicators of environmental change for monitoring the assets, and guidelines for managers and operators using pick lists of options appropriate to the asset and management objectives.

The framework is a mix of generic and site-specific thinking and application. It, therefore, works generically across like-assets and, where sufficient information already exists, it works at site-specific applications. Where sufficient information does not exist, the framework is designed to highlight analogous situations from which indicators and guidelines can be derived until sufficient information is developed at the specific location in question. This system has been applied to scenic icons, wildlife attractions and caves in the West Coast region of the South Island.

Further development of the framework is now taking place. The system will be refined for inclusion in national tourism management guidelines. Working closely with tourism policy groups, and the New Zealand Department of Conservation, the guidelines will be applied to caves, birds, seals and perhaps coastal sand dunes in the first instance. These will be piloted by both tourism operators and the Department of Conservation.

\section{Acknowledgements}

We thank all those who have participated in the discussion workshops or have otherwise made comments on the ideas proposed herein. We also thank Kirsten Crawford and Jeremy Phillips for recent input which has greatly influenced our thinking on matters related to the framework.

\section{Correspondence}

Any correspondence should be directed to Dr Jonet Ward, Environmental Management and Design Division, P.O. Box 84, Lincoln University, Canterbury, New Zealand (Wardj@Lincoln.ac.nz).

\section{Note}

1. The West Coast is one of 14 administrative regions in New Zealand, with a regional council and a regional office of the national Department of Conservation. The region has a total land area of 23,000 square kilometres and a population of 31,500 .

\section{References}

Brabyn, L (1996) Landscape classification using GIS and national digital databases. Landscape Research 21, 277-300.

Booth, K.B., and Cullen, R.C. (1995) Recreation impacts. In P.J. Devlin, R.A. Corbett and C.J. Peebles (eds) Outdoor Recreation in New Zealand: Volume 1-A Review and Synthesis of the Research Literature (pp. 99-135). Wellington: Department of Conservation.

Carden, D. (1998) West Coast Conservancy - Visitor Monitoring Plan Visitor Use and Impacts. Department of Conservation. Hokitika, New Zealand.

Cessford, G.R. (1997) Impacts of visitors on natural and historic resources of conservation significance. Part 2 - research and information needs. Science and Research Internal Report 157. Wellington: Department of Conservation.

Cessford, G.R. (1999a) An approach to assessing the environmental impacts of tourism. Conservation Advisory Science Notes 247. Wellington: Department of Conservation. 
Cessford, G.R. (1999b) Social impacts of visitors to conservation lands. Part 1: Research and information needs. Science and Research Internal Report 171. Wellington: Department of Conservation.

Cessford, G.R. and Dingwall, P.R. (1997) Impacts of visitors on natural and historic resources of conservation significance. Part 1 - workshop proceedings. Science and Research Internal Report 156. Wellington: Department of Conservation.

Clark, R.N. and Stankey, G.H. (1979) The Recreation Opportunity Spectrum: A Frameworkfor Planning, Management and Research. U.S. Department of Agriculture Forest Service, Pacific Northwest Forest and Range Experiment Station.

Constantine, R. (1999) Effects of tourism on marine mammals in New Zealand. Science for Conservation 106. Wellington: Department of Conservation.

Department of Conservation, Ministry for the Environment (2000) New Zealand's biodiversity strategy: Our chance to turn the tide. Wellington: DoC/MFE.

Graefe, A.R. (1993) Visitor impact management: An integrated approach to assessing the impacts of tourism in national parks and protected areas. In A.J. Veal, P. Jonson and G. Cushman (eds) Leisure and Tourism: Social and Environmental Change. Papers from the World Leisure and Recreation Association Congress, Sydney, Australia, 1991 (pp.74-83). Sydney: Centre for Leisure and Tourism Studies, University of Technology.

Hall, C.M. and McArthur, S. (1998) Integrated Heritage Management: Principles and Practice. London: Stationary Office.

Hammitt, W.E. and Cole, D.N. (1998) Wildland Recreation: Ecology and Management. New York: John Wiley.

Kearsley, G.W. and O'Neill, D. (1994) Crowding, satisfaction and displacement: The consequences of growing tourist use of southern New Zealand's conservation estate. In Tourism Down-under: A Tourism Research Conference, 6-9 December (pp. 171-84). Palmerston North, New Zealand: Department of Management Systems. Massey University.

Kliskey, A.D., and Kearsley, G.W. (1993) Mapping multiple perceptions of wilderness in southern New Zealand. Applied Geography 13, 203-23.

Kuss, F.R., Graefe, A.R., and Vaske, J.J. (1990) Visitor Impact Management: A Review of Research (vol. 1). Washington, DC: National Parks and Conservation Association.

Leathwick, J.R. (1995) Climatic relationships of some New Zealand forest tree species. Journal of Vegetation Science 6, 237-48.

Leathwick, J.R. (1998) Are New Zealand's Nothofagus species in equilibrium with their environment? Journal of Vegetation Science 9, 719-32.

Marion, J.L. and Farrell, T.A. (1998) Managing ecotourism visitation in protected areas. In K. Lindbergh, M.E. Wood and D. Engeldrum Ecotourism: A Guide for Planners and Managers. North Bennington, VT: Ecotourism Society.

McArthur, S. (1999) Visitor management in action: An analysis of the development and implementation of visitor management models at Jenolan Caves and Kangaroo Island. PhD thesis, University of Canberra. ACT.

McArthur, S. (2000) Beyond carrying capacity: Introducing a model to monitor and manage visitor activities in forests. In X. Font and J. Tribe (eds) Forest Tourism and Recreation: Case Studies in Environmental Management (pp. 259-78). Wallingford: CABI Publishing.

McEwen, W.M. (1987) Ecological Regions and Districts of New Zealand (4 vols). Wellington: Department of Conservation.

McLean, I. (1995) Which penguin is rarest? N.Z. Science Monthly 6, 10-11.

Ministry for the Environment (1997) Environmental PerformanceIndicators:Proposals for Air, Fresh Water, and Land. Ministry for the Environment, Wellington.

Newsome, P.F.J. (1987) The Vegetative Cover of New Zealand. Water and Soil Miscellaneous Publication No. 112. Wellington: National Water and Soil Conservation Authority. 153 pp.

Park, G. (1995) Nga Uruora - The Groves of Life Ecology and History in a New Zealand Landscape. Victoria University Press. Wellington.

Parliamentary Commissioner for the Environment (1997a) Management of the Environmental Effects Associated with the Tourism Sector. (By P.M. Blaschke, T. Ingram, R. Yska, 
G.W. Kearsley and D.R. Peterson). Wellington: Parliamentary Commissioner for the Environment.

Parliamentary Commissioner for the Environment (1997b) Management of the Environmental Effects Associated with the Tourism Sector - Review of Literature on Environmental Effects. (By G.W. Kearsley and J.E.S. Higham). Wellington: Parliamentary Commissioner for the Environment.

Robertson, C. (1993) Effects of nature tourism on marine wildlife. In Proceedings of the Marine Conservation and Wildife Protection Conference 1992 (pp. 53-60). Held at Auckland University. Wellington: New Zealand Conservation Authority.

Roggenbuck, J.R., Williams, D.R., Watson, A.E. (1993) Defining acceptable conditions in wilderness. Environmental Management 17 (2), 187-97.

Stankey, G.H., Cole, D.N., Lucas, R.C., Petersen, M.E. and Frissell, S.S. (1985) The Limits of Acceptable Change (LAC) System for Wilderness Planning. USDA Forest Service General Technical Report INT-176. Ogden, UT.

Stephens, T. (1999) Measuring conservation achievement. In P.M. Blaschke and K.C. Green (eds) Biodiversity Now! Selected Papers from the Joint NZ Ecological Society/NZ Entomological Society 1997. Wellington: Department of Conservation.

Tourism Strategy Group (2001) New Zealand Tourism Strategy 2010. New Zealand: Tourism Strategy Group.

Urlich, S.C., Ward, J.C., and Hughey, K.F.D. (2001) Environmental Indicators of Tourism Impacts on Three Natural Assets of the West Coast, Aotearoa New Zealand. Tourism Recreation, Research and Education Centre. Lincoln University, New Zealand. Report no. $42 / 2001$.

Walls, G. (1999) Visitor impacts on freshwater avifauna in New Zealand. Conservation Advisory Science Notes 240. Wellington: Department of Conservation.

Ward, J.C., and Beanland, R.A. (1995) Development of Environmental Indicators for Tourism in Natural Areas: A Preliminary Study. Information Paper no. 53. Centre for Resource Management/ Lincoln Environmental. Lincoln University, New Zealand.

Ward, J.C., and Beanland, R.A. (1996) Biophysical Impacts of Tourism. Information Paper no. 56. Centre for Resource Management/ Lincoln Environmental. Lincoln University, New Zealand.

Ward, J.C. and Lambie, J.S. (1999) Monitoring Changes in Wetland Extent: An Environmental Performance Indicator for Wetlands. Report to the Sustainable Management Fund, Ministry for the Environment. Lincoln Environmental, Lincoln University. New Zealand.

Worthy, T.H. (1990) Inventory of New Zealand caves and karst of international, national and regional importance (2nd edn). Geological Society of New Zealand Miscellaneous Publication 47. Lower Hutt. 